\title{
Factors Affecting Contractors' Bidding Decisions for Construction Projects in Nigeria
}

\author{
*Opeyemi Olanrewaju Oyeyipo', Koleola Tunwase Odusami², Rapheal \\ Abiodun Ojelabi ${ }^{3}$ and Adedeji Olushola Afolabi3
}

Published online: 21 December 2016

To cite this article: Opeyemi Olanrewaju Oyeyipo, Koleola Tunwase Odusami, Rapheal Abiodun Ojelabi and Adedej Olushola Afolabi. (2016). Factors affecting contractors' bidding decisions for construction projects in Nigeria. Journal of Construction in Developing Countries, 21 (2): 21-35. https://dx.doi.org/10.21315/jcdc2016.21.2.2.

To link to this article: https://dx.doi.org/10.21315/jcdc2016.21.2.2

\begin{abstract}
Bidding is the most common means by which contractors obtain work. The construction industry accounts for approximately three quarters of the Gross Domestic Product (GDP) in the country. It is generally believed that wrong bidding practice is a major contributor to the construction industry's inefficiency. This means that any improvement in bidding has the potential to enhance the industry's performance, improve the quality of the decision-making process and assist in achieving the strategic objective of contracting organisations. In an effort to uncover the main factors that characterise the bid/no bid decision of contracting organisations, a study to evaluate the factors that affect contractors' decisions to bid for a project and to evaluate the importance of the identified factors to decision makers was conducted. A structured questionnaire was used as the principal instrument for collecting data from respondents. A total sample of 100 was drawn from these collections of construction contractors from Lagos state. Fifty were completed and returned, representing a 50\% response rate. Frequency, percentage, mean score and Spearman's correlation were used in analysing data collected for the study. The results indicate that the financial capability of clients, availability of capital and availability of material are the most important factors that contractors consider when making a bid/no bid decision. The study also reveals that competition (number and identity of competitors) does not have significant influence on contractors' bidding decisions. The study recommends that contractors should also build their reputations in the construction industry by acquiring technical competencies and capabilities as these qualities have become important considerations in assessing contractors' competiveness, as well as being key indicators of successful tendering in construction projects.
\end{abstract}

Keywords: Bidding, Competition, Contractors, Decision making, Tender

\section{INTRODUCTION}

In most countries, the construction industry is a competitive business environment driven by a lowest cost mentality (Dulaimi and Shan, 2002). Most construction projects are awarded on the basis of the lowest tender sum, although a number of other factors are considered in addition to cost. Most construction projects are let through competitive bidding, which requires that roles of the client and contractor be duly defined in black and white. The construction industry contains many

\footnotetext{
'Department of Quantity Surveying, Bells University of Technology, Ota, Ogun, NIGERIA

2Department of Building, University of Lagos, Akoka, Yaba, Lagos, NIGERIA

${ }^{3}$ Department of Building, Covenant University, Ota, Ogun, NIGERIA

*Corresponding author: soldout5812@yahoo.com

(C) Penerbit Universiti Sains Malaysia, 2016
} 
buyers and sellers, even for construction projects, hence the need for some form of competition/bidding.

One of the most crucial decisions that is regularly exercised by construction contractors is to determine whether to bid on a certain project (El-Mashaleh et al. 2014). The preparation and submission of bids for construction work is a means by which contractors obtain construction work and their likes. Competitive bidding is the route for obtaining a sizeable proportion of construction business by contractors globally. Bidding is said to be achieved in a fair way, set out to produce the lowest commercially viable tender price in the current market condition (Harris and McCaffer, 2000). Some contractors conduct construction activities without actually winning a tender but most contractors will only survive and make profit in the industry by winning tenders.

Bidding involves contractors making strategic decisions as it concerns the financial, managerial, manpower and physical resources of the firm before considering embarking on the project (Odusote and Fellow, 1992). Most significant decisions that must be made by the contractor's firm will centre on whether to bid (Egemen and Mohammed, 2007). The ability of contractors to address various bidding situations is an important ingredient for survival, particularly in today's competitive market. The different bidding situations together with the decision involved in the conversion of the estimate into a tender bid is often considered to be the most important step in the bidding process.

Lifson and Shaifer (1982) argue that knowing the importance of the factors influencing the decision-making process would allow key and major decisions to be reviewed and discussed regularly. The management of contracting organisations are expected to make firm decisions on bidding to achieve the long-term objectives of the organisation. Contractors tend to make strategic decisions in respect to project selection, i.e., whether for a job (Oo, Drew and Lo, 2008, Shash, 1993; Lowe and Parvar, 2004). The judgement process includes the consideration of the different factors affecting tendering in a bid to arrive at an informed decision that would reflect positively on the organisation as a whole.

Contractors need to consider numerous factors when evaluating their bids (Dozzi, AbouRizk and Schrooeder, 1996). A number of factors are critical in the decision-making process of whether to bid. Various researchers have presented factors that affect the bid/no bid decision. Odusote and Fellow (1992) highlighted 10 important factors that affect the bid/no bid decision: the identity and reputation of the client, physical resources necessary to carry out the project, the present state of the company's workload, and the ability of the client to pay. Others include the margin of profit involved, the availability of work (both current and potential), the financial resources necessary to carry out the project, the identity of the consultants, the time available in which to tender and the type of work. Shash (1993) conducted a study among top UK contractors and noted that project size, owner promoter, contract conditions, type of contract, project cash flow, current workload, past profit in similar projects, need for work, tendering method, number of competitors tendering, and experience in projects are some of the factors that affect their project selection decision; he identified need for the work, number of competitors and experience as the three major factors that affect a contractor's decision to bid. In a study of the bidding behaviour of contractors in Egypt, Hassanein (1996) presented the most important bid/no bid factors as including the financial source, project type, project monetary size, 
project owner, expected competitors, contractor's own strategic objective, current work in hand, degree of hazard/difficulty, prestige of the project and local expertise/labour availability. According to survey findings of contracting firms in Northern Cyprus, Egemen and Mohamed (2007) highlighted a number of other factors to some of the other abovementioned factors, and they include the following: the completeness of the bid document, risk due to current inflation, exchange rate in the country, stability of the exchange rate, policies and legislation regarding licenses, permits and tax policy of the government in the country, threat due to new entrant into the market increasing competitiveness, and monetary and fiscal policies of the government against economic fluctuations, to mention but a few.

Table 1. Factors Affecting Contractors' Decision to Tender as Identified by Some Studies

\begin{tabular}{|c|c|c|c|}
\hline Author & Country & Project Type & Factors Affecting Decision to Tender \\
\hline $\begin{array}{l}\text { Odusote and } \\
\text { Fellows (1992) }\end{array}$ & UK & $\begin{array}{l}\text { Building/civil } \\
\text { engineering }\end{array}$ & $\begin{array}{l}\text { Identity and reputation of the client, } \\
\text { physical resources necessary to carry } \\
\text { out the project, present state of } \\
\text { company's workload, ability of clients } \\
\text { to pay, margin of profits involved and } \\
\text { availability of work }\end{array}$ \\
\hline Shash (1993) & UK & $\begin{array}{l}\text { Building/civil } \\
\text { engineering }\end{array}$ & $\begin{array}{l}\text { Need for work, number of competitors, } \\
\text { contractor's experience in the project, } \\
\text { current workload, client's identity, } \\
\text { project type, project size, tendering } \\
\text { method, risk and project location }\end{array}$ \\
\hline Hassanein (1996) & Egypt & $\begin{array}{l}\text { Building/civil } \\
\text { engineering }\end{array}$ & $\begin{array}{l}\text { Project type, project monetary size, } \\
\text { expected duration, project owner, } \\
\text { financing source, degree of hazard } \\
\text { difficulty, prestige of project, } \\
\text { contractor's own strategic objectives } \\
\text { and current work in hand }\end{array}$ \\
\hline $\begin{array}{l}\text { Fayek, Ghoshal } \\
\text { and AbouRizk } \\
\text { (1999) }\end{array}$ & Canada & $\begin{array}{l}\text { Civil } \\
\text { engineering }\end{array}$ & $\begin{array}{l}\text { Type of project, likelihood of winning } \\
\text { the project, desire for the project, } \\
\text { familiarity with market, familiarity with } \\
\text { geographical area, size of project and } \\
\text { company's strength }\end{array}$ \\
\hline $\begin{array}{l}\text { Wanous, } \\
\text { Boussabaine } \\
\text { and Lewis (2003) }\end{array}$ & Syria & $\begin{array}{l}\text { Building/civil } \\
\text { engineering }\end{array}$ & $\begin{array}{l}\text { Fulfilling the tender conditions imposed } \\
\text { by the client, financial capability of the } \\
\text { client, relations with and reputation of } \\
\text { the client, project size, availability of } \\
\text { time for tendering, and availability of } \\
\text { capital required }\end{array}$ \\
\hline
\end{tabular}

(Continued on next page) 
Table 1. (Continued)

\begin{tabular}{|c|c|c|c|}
\hline $\begin{array}{l}\text { Lowe and Parvar } \\
\text { (2004) }\end{array}$ & UK & $\begin{array}{l}\text { Building/civil } \\
\text { engineering }\end{array}$ & $\begin{array}{l}\text { Company's objectives and policies, } \\
\text { contract conditions/details, workload, } \\
\text { type of work, resource availability, } \\
\text { tender documentation, cost of } \\
\text { preparing tender, contract size, } \\
\text { project location and the contract } \\
\text { buyer or client }\end{array}$ \\
\hline \multirow{3}{*}{$\begin{array}{l}\text { Banki, Esmaeeli } \\
\text { and Ravanshadnia } \\
\text { (2008) }\end{array}$} & \multirow[t]{3}{*}{ Iran } & \multirow[t]{3}{*}{ Building } & $\begin{array}{l}\text { Internal factors: Expertise, experience, } \\
\text { resources and capabilities }\end{array}$ \\
\hline & & & $\begin{array}{l}\text { External factors: Number of bidders, } \\
\text { bidding risk, type of project and cash } \\
\text { flow requirements }\end{array}$ \\
\hline & & & $\begin{array}{l}\text { Environmental factors: Availability of } \\
\text { other projects, availability of qualified } \\
\text { labour and availability of equipment }\end{array}$ \\
\hline $\begin{array}{l}\text { El-Mashaleh et al. } \\
\text { (2014) }\end{array}$ & Jordan & $\begin{array}{l}\text { Building/civil } \\
\text { Engineering }\end{array}$ & $\begin{array}{l}\text { Financial capability of the client, } \\
\text { reputation of the client, identity of the } \\
\text { client, project size, amount of work } \\
\text { currently in hand and project type }\end{array}$ \\
\hline
\end{tabular}

Against this backdrop, this study set out to examine the factors affecting contractors' decision to bid for construction projects in Lagos, Nigeria. This study set out to test the below mentioned research questions:

1. How significant is the difference in the type of contractors on the factors affecting the bid/no decision?

2. Do indigenous and expatriate contractors agree on the factors that affect the $\mathrm{bid} / \mathrm{no}$ bid decision?

\section{RESEARCH METHOD}

Specifically, a cross-sectional research design was used where samples were drawn from the population of study at one point in time. This study was conducted through a questionnaire survey to elicit data on the factors affecting contractors' decisions to bid. The study was conducted in Lagos, which is economically an important city in Nigeria. As the economic and commercial nerve-centre of the country, Lagos has a high volume of construction activities as well as a large concentration of building and civil engineering contractors of various categories and sizes. The targeted population comprised construction firms of all categories (small, medium and large) based in Lagos or conducting construction activities there at the time the study was conducted. It is worthy of note that contracting organisations are classified based on the level of management personnel and ownership. Indigenous contracting organisations are classified thus when the majority of management personnel and ownership is fully indigenous. However, while expatriate contractors have a majority of management personnel and owners being foreigners, partly expatriate contracting organisations have both locals and foreigners among their management personnel. Specifically, managing

24/PENERBIT UNIVERSITI SAINS MALAYSIA 
directors, estimators, contracts managers, construction or project managers, site managers, commercial managers and other key personnel involved in tendering activities of these construction firms were the targeted respondents.

The convenience sampling method was adopted to arrive at the sample size for the study. The convenience sampling technique was set out because there was no updated list of contracting organisations within the study area and the tendency of organisations to refuse to provide information in the research instrument. Of the 100 copies of research questionnaire distributed, 55 were completed and returned, representing a 55\% response rate. The returned copies were scrutinised for errors, omissions, completeness and inconsistencies. Fifty questionnaires were found to be adequately completed.

Respondents were requested to measure the level of importance their firms attach to 48 identified factors that determine contractors' decisions to tender, as well as the mark-up size decision on a 5-point scale $11=$ Not important, $2=$ Of little importance, 3 = Moderately important, $4=$ Important and $5=$ Very important).

\section{RESULTS AND DISCUSSION}

Data collected from the questionnaire responses were analysed and are presented here in the tables. Table 2 shows the summary of the demographic characteristics of the respondents. Chief estimators constitute the highest proportion $(28.0 \%)$ of the respondents, indicating their large involvement in the bidding processes of construction firms. Both managing directors and chief estimators account for $44 \%$ of the total population and site professionals such as architects, quantity surveyors, engineers account for approximately $24 \%$ of the sample that participated in the survey. This confirms that bidding practices are conducted by senior management (Hassanein, 1996; Lowe and Parvar, 2004).

A sizeable proportion $(41 \%)$ of respondents is within the age bracket of 41 years and above. Approximately $98 \%$ of the respondents received formal educations, which put them in the right stead to provide valuable information. Approximately $52 \%$ of respondents have working experience of 11 years and above, which implies that they are sufficiently knowledgeable in construction matters to take an active part in decision making. Quantity surveyors constitute $47.9 \%$ of the respondents - the highest proportion, indicating their involvement in the bidding process of construction firms.

Table 3 shows the characteristics of the responding firm. Most of the responding firms (70.2\%) are involved in main contractor work, and approximately $79.6 \%$ of the respondents are limited liability companies. Of the contracting firms, $78.0 \%$ operate a fully indigenous firm, while the remaining $22 \%$ of the firms are either expatriate or partly expatriate. It is clear that a greater percentage of contractors operating within Lagos are fully indigenous in their ownership and management system. Of respondents, $51.1 \%$ are building and civil engineering contractors and $25.5 \%$ are both electrical and mechanical contractors; building contractors alone constitute $14.9 \%$ of the population. It is evident that the majority of contractors do not specialise in a single type of construction such as building or civil engineering. 
Table 2. Demographic Data of Respondents

\begin{tabular}{|c|c|c|c|}
\hline & Frequency & $\begin{array}{l}\text { Percentage } \\
(\%)\end{array}$ & $\begin{array}{l}\text { Cumulative } \\
\text { Percentage }\end{array}$ \\
\hline \multicolumn{4}{|l|}{ Designation of Respondent $(N=50)$} \\
\hline Chief estimator & 14 & 28 & 28 \\
\hline Project manager & 13 & 26 & 54 \\
\hline Managing director & 8 & 16 & 70 \\
\hline Chief executive officer (CEO) & 3 & 6 & 76 \\
\hline Contract/Site professionals & 12 & 24 & 100 \\
\hline \multicolumn{4}{|l|}{ Age of Respondent ( $N=49)$} \\
\hline $21-30$ years & 4 & 8.2 & 8.2 \\
\hline $31-40$ years & 25 & 51 & 59.2 \\
\hline $41-50$ years & 10 & 20.4 & 79.6 \\
\hline $51-60$ years & 9 & 18.4 & 98 \\
\hline Above 60 years & 1 & 2 & 100 \\
\hline \multicolumn{4}{|l|}{ Academic Qualification ( $N=49$ ) } \\
\hline Ordinary National Diploma (OND) & 1 & 2 & 2 \\
\hline $\begin{array}{l}\text { Higher National Diploma } \\
\text { (HND)/Bachelor of Science (BSC) }\end{array}$ & 30 & 61.2 & 63.3 \\
\hline Post Graduate Diploma (PGD) & 5 & 10.2 & 73.5 \\
\hline $\begin{array}{l}\text { Masters of Science (MSC)/Masters of } \\
\text { Business Administration (MBA) }\end{array}$ & 10 & 20.4 & 93.9 \\
\hline Doctorate of Philosophy (PhD) & 1 & 2 & 95.9 \\
\hline Others & 2 & 4.1 & 100 \\
\hline \multicolumn{4}{|l|}{ Professional Qualification ( $N=38$ ) } \\
\hline Nigerian Institute of Architects (NIA) & 1 & 2.6 & 2.6 \\
\hline Nigerian Society of Engineers (NSE) & 11 & 28.9 & 31.5 \\
\hline Nigerian Institute of Building (NIOB) & 6 & 15.8 & 47.3 \\
\hline $\begin{array}{l}\text { Nigerian Institute of Quantity Surveyors } \\
\text { (NIQS) }\end{array}$ & 19 & 50 & 97 \\
\hline Others & 1 & 2.6 & 100 \\
\hline \multicolumn{4}{|l|}{ Construction Experience $(N=50)$} \\
\hline $1-10$ years & 24 & 48 & 48 \\
\hline $11-20$ years & 10 & 20 & 68 \\
\hline $21-30$ years & 12 & 24 & 92 \\
\hline $31-40$ years & 4 & 8 & 100 \\
\hline \multicolumn{4}{|l|}{ Professional Background ( $N=48$ ) } \\
\hline Architect & 2 & 4.2 & 4.2 \\
\hline Quantity surveyor & 23 & 47.9 & 52.1 \\
\hline Builder & 6 & 12.5 & 64.6 \\
\hline Civil engineer & 6 & 12.5 & 77.2 \\
\hline Electrical engineer & 9 & 18.8 & 95.9 \\
\hline Mechanical engineer & 2 & 4.2 & 100 \\
\hline
\end{tabular}

26/PENERBIT UNIVERSITI SAINS MALAYSIA 
Table 3. Characteristics of Responding Firms

\begin{tabular}{|c|c|c|c|}
\hline & Frequency & $\begin{array}{c}\text { Percentage } \\
(\%)\end{array}$ & $\begin{array}{c}\text { Cumulative } \\
\text { Percentage (\%) }\end{array}$ \\
\hline \multicolumn{4}{|l|}{ Class of Contractor ( $N=47)$} \\
\hline Main contractor & 33 & 70.2 & 70.2 \\
\hline Nominated sub-contractor & 13 & 27.7 & 97.9 \\
\hline Others & 1 & 2.1 & 100.0 \\
\hline \multicolumn{4}{|l|}{ Types of Ownership ( $N=49$ ) } \\
\hline Sole proprietorship & 7 & 14.3 & 14.3 \\
\hline Partnership & 1 & 2.0 & 16.30 \\
\hline Limited liability company & 39 & 79.6 & 95.90 \\
\hline Public limited company & 2 & 4.10 & 100.0 \\
\hline \multicolumn{4}{|c|}{ Organisation Ownership and Management ( $N=50)$} \\
\hline Fully indigenous & 39 & 78.0 & 78.0 \\
\hline Fully expatriate & 11 & 22.0 & 100.0 \\
\hline \multicolumn{4}{|l|}{ Organisation Activity ( $N=47)$} \\
\hline Building only & 7 & 14.9 & 14.9 \\
\hline Civil engineering only & 2 & 4.3 & 19.1 \\
\hline Building and civil engineering & 24 & 51.1 & 70.2 \\
\hline Electrical only & 1 & 2.1 & 72.3 \\
\hline Mechanical and electrical only & 12 & 25.5 & 97.9 \\
\hline Others & 1 & 2.1 & 100.0 \\
\hline \multicolumn{4}{|l|}{ Construction Activity $(N=41)$} \\
\hline New works & 7 & 17.1 & 17.1 \\
\hline General contracting & 31 & 75.6 & 92.7 \\
\hline Others & 3 & 7.3 & 100.0 \\
\hline
\end{tabular}

The construction activity in which the respondent is engaged is presented in Table 3 and $75.6 \%$ of the contractors undertake general contracting, while $17.1 \%$ of them are involved in new works.

Table 4. Client Source

\begin{tabular}{llcc}
\hline Client Source & $\boldsymbol{N}$ & Mean & Rank \\
\hline Corporate bodies & 49 & 4.14 & 1 \\
Individual & 48 & 3.83 & 2 \\
Government & 49 & 2.86 & 3 \\
\hline
\end{tabular}

Table 4 indicates the mean score of the client source of contractors in Lagos state. Private organisations with a mean score of 4.14 are the major source of construction for contractors. This is followed closely by individuals with a mean rating of 3.83, while government and public agencies with a mean score of 2.86 are a less frequent source of construction work for the contractors. This appears to 
be contrary to the generally held belief that government and public sector clients constitute the major source of construction contracts

\section{Factors That Affect Contractors' Bid/No Bid Decisions}

In Table 5, the factors affecting the bid/no bid decisions are highlighted. The mean scores of the factors that affect the bid/no bid decisions are shown in the table below. The mean limit is 4.00 , and any factor equal to or above 4.00 is considered as important in making the bid/no bid decisions while factors below the mean limit are regarded as less important.

Table 5. Factors Affecting the Bid/No Bid Decisions

\begin{tabular}{lccc}
\hline Factors Affecting the Bid/No Bid Decision & N & Mean & Rank \\
\hline Financial capability of the client & 48 & 4.56 & 1 \\
Availability of capital & 49 & 4.53 & 2 \\
Availability of materials & 44 & 4.39 & 3 \\
Fulfilling the "to tender" condition & 48 & 4.33 & 4 \\
Chances of obtaining the job & 46 & 4.33 & 4 \\
Project size & 49 & 4.29 & 6 \\
Need for work & 49 & 4.29 & 6 \\
Profitability/profit potential) & 50 & 4.28 & 8 \\
Availability of labour/equipment & 48 & 4.21 & 9 \\
Relations with and reputation to client & 49 & 4.20 & 10 \\
Experience in similar project & 48 & 4.19 & 11 \\
Type of contract & 49 & 4.18 & 12 \\
Project type & 50 & 4.16 & 13 \\
Site accessibility & 48 & 4.15 & 14 \\
Degree of hazard/safety & 50 & 4.14 & 15 \\
Type of owner/client identity & 50 & 4.10 & 16 \\
General overhead & 46 & 4.09 & 17 \\
Method of construction & 47 & 4.09 & 17 \\
Site condition & 48 & 4.08 & 19 \\
Anticipated rate of return & 49 & 4.08 & 19 \\
Risk involved in investment & 49 & 4.06 & 21 \\
Technological difficulty of project beyond the capability of & 48 & 4.02 & 22 \\
the firm & & & \\
Owner's requirement & 49 & 4.02 & 22 \\
Risk of fluctuation in material price & 49 & 4.00 & 24 \\
Prequalification requirement & 50 & 4.00 & 24 \\
Imported materials and equipment & 48 & 3.96 & 26 \\
Completeness of documents & 47 & 3.91 & 27 \\
Project location & 50 & 3.90 & 28 \\
Duration of project & 49 & 3.86 & 29 \\
Project's possible contribution to breaking into new markets & 48 & 3.83 & 30 \\
\hline & & & \\
\hline & 1609 \\
\hline
\end{tabular}

(Continued on next page) 
Table 5. (Continued)

\begin{tabular}{llll}
\hline Government legislation & 49 & 3.82 & 31 \\
Tendering duration & 50 & 3.72 & 32 \\
Tendering method & 50 & 3.72 & 32 \\
Requirement of bond capacity & 47 & 3.68 & 34 \\
Current workload & 49 & 3.67 & 35 \\
Value of liquidated damages & 49 & 3.61 & 36 \\
Market direction & 46 & 3.59 & 37 \\
Availability of other projects & 48 & 3.56 & 38 \\
Tax liability & 49 & 3.55 & 39 \\
Bidding document price & 49 & 3.51 & 40 \\
Site clearance of obstruction & 48 & 3.48 & 41 \\
Competitiveness of competitors & 49 & 3.45 & 42 \\
Insurance premium & 49 & 3.43 & 43 \\
Competitive environment & 48 & 3.42 & 44 \\
Number of competitors & 49 & 3.39 & 45 \\
Uncertainty due to weather conditions & 48 & 3.38 & 46 \\
Portion subcontracted to others & 48 & 3.15 & 47 \\
Identity of competitors & 50 & 3.08 & 48 \\
\hline
\end{tabular}

Table 5 indicates that the financial capability of the client with a mean score of 4.56 is the most important factor considered by contractors when arriving at a decision on whether to bid for a construction project. Other important factors include the availability of capital, availability of materials, fulfilling the "to tender" condition, chances of obtaining the job, project size, and need for work with mean scores of $4.53,4.39,4.33,4.33,4.29$ and 4.16 , respectively. The number of competitors, uncertainty due to weather conditions, and portion subcontracted to others are shown in the table to be less important to the bid/no bid decision, while the identity of competitors with a mean score of 3.08 is said to exert the least importance on the bid/no bid decision.

This study identifies the financial capability of the client as the most important factor considered for bid/no bid decisions by contractors when bidding for a construction project. Research conducted by El-Mashaleh et al. (2014) confirmed that of the key bidding factors considered by top Jordan contractors, the financial capability of the client is the most important factor affecting contractors. Studies by Wanous, Boussabaine and Lewis (2000) reveal the capability of the client to pay as being a very important factor influencing contractors' decision to tender for a project, although it was not considered as an important factor in contractors' bidding decision in the research findings of Shash (1993), Lowe and Parvar (2004) and Fayek, Ghoshal and AbouRizk (1999).

The availability of capital, availability of materials, fulfilling the tender condition, chances of obtaining the job, project size and the need for work also emerge in this study as important factors in contractors' bidding decisions. While Wanous, Boussabaine and Lewis (2000) identified fulfilling the tender conditions, the availability of capital, the availability of materials and project size as important factors. Shash (1993) and Hassanein (1996) reveal only project size as important 
factor in contractors' bidding decisions. Another interesting finding of the study is that need for work and number of competitors tendering, which ranked as the two most important factors in bidding decisions in research conducted by Shash (1993) were not considered important in the current study. Nigerian contractors appear to play down competition because it is considered that other factors related to performance on past projects and most importantly, their relationship with project stakeholders might influence their chances of obtaining the job.

\section{Significant Differences of the Types of Contractors on the Factors Affecting Decisions to Bid}

This section was designed to test the significant differences in the most important factors considered by the two classes of contractors (comparison between indigenous and expatriate contractors) when making the bid/no bid decisions. The most important factors affecting bid/no bid decisions according to indigenous and expatriate contractors are shown in Table 6. From this table, the mean score shows that the most important factors affecting the bid/no bid decisions of indigenous contractors are the availability of capital, financial capability of client, fulfilling the "to tender" conditions, degree of hazard and availability of materials. Similarly, the result as depicted by the mean score in Table 6 indicates that expatriate construction firms consider first the client's ability to pay, followed by the organisation's chances of obtaining the job, the project size, type of owner/client identity and the site condition, as important factors affecting the choice of projects to bid or to not bid for. More significantly, as shown in Table 6, at p-value $<0.05$, the two categories of contractors consider the financial capability of the client, number of competitors, current workload and project size are important factors that influence their bidding decision.

The financial capability of the client is considered important by the two classes of contractors because it assesses the ability of the client to pay for the construction work to be executed. This is, however, in contrast to the availability of capital, which is considered important only by indigenous contractors. The availability of capital in preparation for construction projects is important for reducing the tendency of late and/or non-payment by clients, which would hinder the progress of work and ultimately might cause the abandonment of the project.

Moreover, Table 6 shows the mean score of the factors considered least important by indigenous and expatriate contractors. For indigenous contractors, uncertainty due to weather conditions, portion sub-contracted to others and identity of competitors make up the list. However, expatriate contractors agree with indigenous contractors that the identity of competitors is one of the least important factors considered. Uncertainty due to weather, the requirement of bond capacity and bidding document price are the other factors considered least by expatriate contractors during the tender process. More significantly, as shown in Table 6 , at $p$-value $<0.05$, no factor was considered least among the highlighted factors by indigenous and expatriate contractors 
Table 6. Mann-Whitney Statistical Test of Significant Differences in the Types of Contractors on Important Bid/No Bid Factors

\begin{tabular}{|c|c|c|c|c|c|c|c|c|}
\hline \multirow{2}{*}{ Bid/No Bid Factors } & \multicolumn{2}{|c|}{ Indigenous } & \multicolumn{2}{|c|}{ Expatriate } & \multirow{2}{*}{$\begin{array}{c}\text { Mann } \\
\text { Whitney U }\end{array}$} & \multirow{2}{*}{ Z Test } & \multirow{2}{*}{$\begin{array}{c}p- \\
\text { Value }\end{array}$} & \multirow{2}{*}{ Sig. } \\
\hline & $M$ & $\mathbf{R}$ & $M$ & $\mathbf{R}$ & & & & \\
\hline Need for work & 4.32 & 5 & 4.40 & 6 & 1.00 & -0.787 & 0.86 & NS \\
\hline Current work load & 3.70 & 39 & 3.60 & 23 & 2.00 & -1.067 & 0.034 & $S$ \\
\hline $\begin{array}{l}\text { Portion sub-contracted } \\
\text { to others }\end{array}$ & 3.35 & 47 & 3.60 & 23 & 4.00 & -2.140 & 0.09 & NS \\
\hline General overhead & 4.12 & 19 & 3.80 & 17 & 2.00 & -1.589 & 0.16 & NS \\
\hline $\begin{array}{l}\text { Relations with and } \\
\text { reputation of client }\end{array}$ & 4.26 & 10 & 4.40 & 6 & 1.00 & -1.02 & 0.908 & NS \\
\hline $\begin{array}{l}\text { Profitability (profit } \\
\text { potential) }\end{array}$ & 4.25 & 11 & 4.40 & 6 & 1.00 & -2.22 & 0.34 & NS \\
\hline $\begin{array}{l}\text { Experience in similar } \\
\text { project }\end{array}$ & 4.00 & 26 & 4.40 & 6 & 2.00 & -1.16 & 0.23 & NS \\
\hline $\begin{array}{l}\text { Fulfilling the "to tender" } \\
\text { condition }\end{array}$ & 4.41 & 3 & 3.60 & 23 & 4.00 & -0.356 & 0.913 & NS \\
\hline Method of construction & 4.00 & 26 & 4.20 & 11 & 1.00 & -1.262 & 0.54 & NS \\
\hline Project size & 4.07 & 20 & 4.80 & 2 & 1.00 & -1.789 & 0.04 & $S$ \\
\hline Project type & 4.07 & 20 & 3.60 & 23 & 2.00 & -0.617 & 0.111 & NS \\
\hline Project location & 3.89 & 29 & 4.00 & 16 & 4.00 & -1.444 & 0.384 & NS \\
\hline Duration of project & 4.04 & 25 & 3.60 & 23 & 2.00 & -2.10 & 0.378 & NS \\
\hline $\begin{array}{l}\text { Type of owner/client } \\
\text { identity }\end{array}$ & 4.25 & 11 & 4.80 & 2 & 3.00 & -1.89 & 0.555 & NS \\
\hline $\begin{array}{l}\text { Degree of hazard } \\
\text { (safety) }\end{array}$ & 4.36 & 4 & 4.20 & 11 & 1.00 & -0.453 & 0.67 & NS \\
\hline Site condition & 4.07 & 20 & 4.60 & 5 & 2.00 & -2.03 & 0.134 & NS \\
\hline $\begin{array}{l}\text { Project's possible } \\
\text { contribution to breaking } \\
\text { into new markets }\end{array}$ & 3.78 & 37 & 3.00 & 37 & 1.00 & -0.233 & 0.46 & NS \\
\hline $\begin{array}{l}\text { Financial capability of } \\
\text { the client }\end{array}$ & 4.52 & 2 & 5.00 & 1 & 2.00 & -0.444 & 0.02 & S \\
\hline Tendering method & 3.75 & 38 & 3.80 & 17 & 1.00 & -0.367 & 0.96 & NS \\
\hline Tendering duration & 3.89 & 29 & 3.60 & 23 & 1.00 & -0.978 & 0.36 & NS \\
\hline $\begin{array}{l}\text { Prequalification } \\
\text { requirement }\end{array}$ & 4.29 & 8 & 3.60 & 23 & 3.00 & -0.890 & 0.10 & NS \\
\hline Number of competitors & 3.59 & 42 & 3.00 & 37 & 1.00 & -0.456 & 0.03 & $S$ \\
\hline Identity of competitors & 3.25 & 48 & 2.40 & 48 & 3.00 & -1.477 & 0.78 & NS \\
\hline $\begin{array}{l}\text { Availability of other } \\
\text { projects }\end{array}$ & 3.63 & 40 & 3.00 & 37 & 2.00 & -0.904 & 0.571 & NS \\
\hline $\begin{array}{l}\text { Requirement of bond } \\
\text { capacity }\end{array}$ & 3.81 & 34 & 2.50 & 47 & 3.00 & -0.889 & 0.108 & NS \\
\hline Bidding document price & 3.89 & 29 & 2.60 & 44 & 2.00 & -0.178 & 0.345 & NS \\
\hline $\begin{array}{l}\text { Competitiveness of } \\
\text { competitors }\end{array}$ & 3.61 & 41 & 3.00 & 37 & 1.00 & -0.08 & 0.555 & NS \\
\hline
\end{tabular}

(Continued on next page) 
Opeyemi Olanrewaju Oyeyipo et al.

Table 6. (Continued)

\begin{tabular}{|c|c|c|c|c|c|c|c|c|}
\hline $\begin{array}{l}\text { Competitive } \\
\text { environment }\end{array}$ & 3.56 & 44 & 3.00 & 37 & 2.00 & -0.216 & 0.98 & NS \\
\hline $\begin{array}{l}\text { Chances of obtaining } \\
\text { the job }\end{array}$ & 4.31 & 7 & 4.80 & 2 & 2.00 & -0.777 & 0.340 & NS \\
\hline Availability of capital & 4.75 & 1 & 4.20 & 11 & 3.00 & -1.346 & 0.321 & NS \\
\hline $\begin{array}{l}\text { Risk involved in } \\
\text { investment }\end{array}$ & 4.18 & 14 & 4.20 & 11 & 1.00 & -2.111 & 0.708 & NS \\
\hline $\begin{array}{l}\text { Anticipated rate of } \\
\text { return }\end{array}$ & 4.18 & 14 & 3.40 & 33 & 3.00 & -1.569 & 0.93 & NS \\
\hline Government legislation & 3.79 & 35 & 3.60 & 23 & 1.00 & -2.111 & 0.221 & NS \\
\hline Tax liability & 3.79 & 35 & 3.20 & 35 & 2.00 & -0.222 & 0.55 & NS \\
\hline $\begin{array}{l}\text { Availability of } \\
\text { labour/equipment }\end{array}$ & 4.14 & 14 & 3.80 & 17 & 1.00 & -0.494 & 0.89 & NS \\
\hline Market direction & 3.88 & 32 & 3.00 & 37 & 1.00 & -0.555 & 0.19 & NS \\
\hline Availability of materials & 4.32 & 5 & 4.20 & 11 & 1.00 & -0.324 & 0.861 & NS \\
\hline Type of contract & 4.29 & 8 & 3.80 & 17 & 2.00 & -0.197 & 0.57 & NS \\
\hline $\begin{array}{l}\text { Completeness of } \\
\text { documents }\end{array}$ & 4.07 & 20 & 3.40 & 33 & 2.00 & -1.89 & 0.69 & NS \\
\hline Owner's requirements & 4.14 & 14 & 3.80 & 17 & 3.00 & -2.198 & 0.371 & NS \\
\hline $\begin{array}{l}\text { Value of liquidated } \\
\text { damages }\end{array}$ & 3.82 & 33 & 3.80 & 17 & 1.00 & -1.111 & 0.789 & NS \\
\hline $\begin{array}{l}\text { Risk of fluctuation in } \\
\text { material price }\end{array}$ & 3.93 & 28 & 4.40 & 6 & 2.00 & -0.346 & 0.315 & NS \\
\hline Insurance premium & 3.57 & 43 & 3.60 & 23 & 1.00 & -0.676 & 0.088 & NS \\
\hline Site accessibility & 4.21 & 13 & 3.60 & 23 & 2.00 & -0.743 & 0.89 & NS \\
\hline $\begin{array}{l}\text { Uncertainty due to } \\
\text { weather conditions }\end{array}$ & 3.39 & 46 & 2.60 & 44 & 2.00 & -1.86 & 0.02 & NS \\
\hline $\begin{array}{l}\text { Imported materials and } \\
\text { equipment }\end{array}$ & 4.07 & 20 & 3.20 & 35 & 2.00 & -0.677 & 0.443 & NS \\
\hline $\begin{array}{l}\text { Technological difficulty } \\
\text { of project being beyond } \\
\text { the capability of the firm }\end{array}$ & 4.18 & 14 & 3.00 & 37 & 3.00 & -0.967 & 0.777 & NS \\
\hline $\begin{array}{l}\text { Site clearance of } \\
\text { obstruction }\end{array}$ & 3.46 & 45 & 2.60 & 44 & 2.00 & -1.26 & 0.91 & NS \\
\hline
\end{tabular}

Notes: $M=$ Mean; $R=$ Rank; Sig. = Significant; $N S=$ Not significant

\section{Agreement of Contractors on the Important Factors Affecting Bidding Decisions}

This section examines the level of agreement of indigenous and expatriate contractors on the factors affecting bid/no bid decisions for construction projects. The Kendall co-efficient of concordance was used to test the level of agreement between the two types of contractors. The result is presented in Table 7 as depicted below. 
Table 7. Test of Agreement on Ranking of Important Bid/No Bid Factors

\begin{tabular}{lcccccc}
\hline Comparison of Contractors & $\begin{array}{c}\text { Correlation Co- } \\
\text { Efficient (Rs) }\end{array}$ & $\boldsymbol{t}$-cal & $\boldsymbol{t}$-tab & Agreement & $\boldsymbol{p}$-Value \\
\hline Indigenous and expatriate & 0.61 & 5.22 & 1.679 & No & $p<0.05$ \\
\hline
\end{tabular}

Table 7 shows the result of the combination of Spearman's rank correlation coefficient, $t$-values, and the decision rule of agreement between contractors on the factors affecting the bid/no bid decisions within the industry. From Table 7, it can be observed that the $t$-cal of 5.22 is greater than the t-tab of 1.679 with 46 degrees of freedom $(v=46)$ at the $p<0.05$ significance level, and it can then be concluded that there is no agreement between indigenous and expatriate contractors on the factors that affect the bid/no bid decision.

This study advocates that no agreement exists between expatriate and indigenous contractors on the important factors that determine bid/no bid decisions. The study is similar to the one conducted by Hassanein (1996), in which he added his voice on the non-agreement of factors affecting indigenous contractors and foreign contractors in Egypt.

\section{CONCLUSION AND RECOMMENDATION}

The findings of this study serve as a basis for making the following conclusions and recommendations. The purpose of this paper is to evaluate the important factors local and expatriate contracting organisations consider in bidding decisions in the Nigerian construction industry. This paper highlighted the major factors considered by contractors and compared them with related research in other parts of the world.

Furthermore, this paper tested the significant differences in the means of factors affecting indigenous and expatriate contractors in bidding decisions for construction projects. The Mann Whitney $U$ statistical test revealed that three $\mathrm{bid} / \mathrm{no}$ bid factors are significant to both indigenous and expatriate contractors in making bidding decisions. These factors include the financial capability of the client, project size and number of competitors. This is in agreement with Hatush and Skitmore (1997), who considered the number of competitors a very important factor in the bidding decisions of construction companies.

Finally, the Kendall concordance coefficient was used to test the level of agreement among indigenous and expatriate contractors regarding the 48 $\mathrm{bid} / \mathrm{no}$ bid decision factors for construction projects. Kendall's coefficient of concordance provided sufficient evidence to conclude that there is no significant degree of agreement among local and foreign contractors concerning bid/no decisions for construction projects in Nigeria.

When considering tenders for construction projects, building contractors should give primary attention to the client capability to pay for the work, project size and the number of competitors, if known, among other factors peculiar to the project. Contractors should also build their reputations in the construction industry by acquiring technical competencies and capabilities, as these qualities have become important considerations in assessing contractors' competiveness and 
key indicators of successful tendering in construction projects. Finally, contractors should not rely solely on their relationship with the project stakeholders to obtain construction contracts, as this may not be sufficient to guaranteeing their chance of winning tenders, but should rather build their reputations, performance, technical competence and managerial capabilities.

A suggested area of future studies could include but are not limited to examining the association between bid/no bid factors and bidding decisions in real life construction projects within the six geographical zones of the country.

\section{REFERENCES}

Banki, M.T., Esmaeeli, B. and Ravanshadnia, M. (2008). The assessment of bidding strategy of Iranian construction firm. International Journal of Management Science and Engineering Management, 4(2): 153-160.

Dozzi, S.P., AbouRizk, S.M. and Schroeder, S.L. (1996). Utility-theory model for bid mark-up decisions. ASCE Journal of Construction Engineering and Management, 122(2): 119-124. http://dx.doi.org/10.1061/(ASCE)0733-9364 (1996) 122:2(119)

Dulaimi, M.F. and Shan, H.G. (2002). The factors influencing bid mark-up decisions of large and medium-size contractors in Singapore. Construction Management and Economics, 20(7): 601-610. http://dx.doi.org/10.1080/ 01446190210159890.

Egemen, M. and Mohamed, A.N. (2007). A framework for contractors to reach strategically correct bid/no bid and mark-up size decisions. Building and Environment, 42(3): 1373-1385. http://dx.doi.org/10.1016/j.buildenv.2005. 11.016.

El-Mashaleh, M.S., Al-Jundi, A., Mattar, S., Ali, R.A. and Al-Hammad, J. (2014). Understanding key bidding factors considered by top Jordan contractors. Jordan Journal of Civil Engineering, 8(4): 455-464.

Fayek, A., Ghoshal, I. and AbouRizk, S. (1999). A survey of bidding practices of Canadian civil engineering construction contractors. Canadian Journal of Civil Engineering, 26(1): 13-25. http://dx.doi.org/10.1139/198-038.

Harris, F. and McCaffer, R. (2000). Modern Construction Management. 5th Ed. Oxford: Blackwell Science.

Hassanein, A.G. (1996). Factors affecting the bidding behaviour of contractors in Egypt. Building Research and Information, 24(4): 228-236. http://dx.doi.org/10.1080/09613219608727534.

Hatush, Z. and Skitmore, M. (1997). Evaluating contractor's prequalification data: selection criteria and project success factors. Construction Management and Economics, 15(2): 129-147. http://dx.doi.org/10.1080/0144619970000 0002.

Lifson, M.W. and Shaifer, E.F. (1982). Decision and Risk Analysis for Construction Management. New York: John Wiley and Sons.

Lowe, D.J. and Parvar, J. (2004). A logistic regression approach to modeling the contractor's decision to bid. Construction Management and Economics, 22(6): 643-653. http://dx.doi.org/10.1080/01446190310001649056. 
Odusote, O.O. and Fellows, R.F. (1992). An examination of the importance of resource considerations when contractors make project selection decisions. Construction Management and Economics, 10(2): 137-151. http://dx.doi.org/10.1080/01446199200000013.

Oo, B.L., Drew, D.S. and LO, H.P. (2008). A comparison of contractors' decision to bid behaviour according to different market environments. International Journal of Project Management, 26(4): 439-447. http://dx.doi.org/10.1016/ j.ijproman.2007.06.001.

Shash, A.A. (1993). Factors considered in tendering decisions by top UK contractors. Construction Management and Economics, 11(2): 111-118. http://dx.doi.org/10.1080/01446199300000004.

Wanous, M., Boussabaine, A.H. and Lewis, J. (2000). To bid or not to bid: A parametric solution. Construction Management and Economics, 18(4): 457466. http://dx.doi.org/10.1080/01446190050024879.

Wanous, M., Boussabaine, H.A. and Lewis, J. (2003). A neural network bid/no bid model: The case for contractors in Syria. Construction Management and Economics, 21 (7): 737-744. http://dx.doi.org/10.1080/0144619032000093323.

Wong, C.H., Holt, G.D. and Cooper, P.A. (2000). Lowest price or value? Investigation of UK construction clients' tender selection process. Construction Management and Economics, 18(7): 767-774. http://dx.doi.org/10.1080/014461900433050. 